\title{
The Analysis Of Implementation Program Of Adolescent Reproductive Health Service In North Barito Regency, Center Kalimantan Of Indonesia
}

\author{
Adriana Palimbo ${ }^{1 *}$ \\ ${ }^{1}$ Department of Midwifery STIKES Sari Mulia Banjarmasin, Indonesia \\ *adriana_palimbo@stikessarimulia.ac.id \\ Sukamto $^{2}$ \\ ${ }^{2}$ The Health Office of Banjarmasin Province, Banjarmasin, Indonesia \\ Sukamto@gmail.com \\ Erna Susanti ${ }^{1}$ \\ ${ }^{1}$ Department of Midwifery STIKES Sari Mulia Banjarmasin, Indonesia \\ Erna_susanti@gmail.com
}

\begin{abstract}
Objective: Knowing the implementation of Youth Reproduction Health (KRR) program in North Barito District. It is seen from four aspects of Health Services System which include aspects of input, process, output, and impact. This study also specifically aims to obtain information on the implementation of promotional and preventive strategic efforts needed through Adolescent Reproductive Health (KRR), and specifically to serve Youth Care Program (PKPR). The reason for this problem is based on the increasing cases of HIV-infected adolescents in Barito Utara District, Central Kalimantan, Indonesia since 2013.

Method: The research design used was qualitative approach with sampling technique of Purposive Sampling which consisted of 19 people consist of 4 main informants and 15 informants triangulation in four working area of Public Health Center at North Barito Health Office. Data collection techniques were conducted with in-depth interviews.

Result: The result of the research shows that information on health care service of the adolescent program by four Puskesmas have not all been going well, there is some research indicating that not yet maximal, among others Peer Counselor Training, Human Resources, Funding, and Infrastructure Facility.

Conclusion: Fulfillment of Human Resources, Facilities and Infrastructure as well as 6 aspects The process of implementation of Reproductive Health of Adolescents especially on Health Care Services Youth at the level of Puskesmas the maximum and quality play an important role in realizing healthy teenagers and is expected to reduce health problems in adolescents.
\end{abstract}

Keywords: Adolescent Care Health Services, Adolescent Reproductive Health, Health Services System, Program Implementation

\section{INTRODUCTION}

North Barito regency is a region in Central Kalimantan Province which is geographically located in the central part of Indonesia. Based on the description of Topography, the area of North Barito Regency is $8,300 \mathrm{~km}$ with the population of 159.402 
people (in 2015) with population density 19,21 soul / km2. North Barito District has 9 subdistricts, consisting of 10 villages and 93 villages. The North Barito region is in the hinterland of the Barito River area at an altitude of 201,730 $\mathrm{m}$ above sea level [1].

Achievement of health development outcomes The Human Development Index value of North Barito Regency in 2013 is 76\%. This data increases compared to 2012 by $76 \%$. HDI Kab. Barut occupies the second highest ranking of 14 districts/cities in Central Kalimantan [2].

Youth as a young generation is prepared to be qualified and independent human resources so it needs strategic efforts that are promotive and preventive [3].

Teenage is a vulnerable age because it has a high curiosity and want to try new things, coupled with the rapid technological advances make teenagers can fall into the free association because of its daring to try without the thought of a mature [4][5].

These issues and policies are reinforced by Michelle J Hindin on Youth monitoring and reproductive health who argue that 2016 is a critical year for adolescent sexual and reproductive health, when two major global health strategies Agenda 2030 for Sustainable Development and the United States Global Strategy for Women's Health, Children and Adolescents begin to take effect [6][7]. So that if not given information / services teenagers correct and correct, then adolescent behavior often leads to risky behavior, among others, the abuse of drugs (Narcotics, Psychotropic and other addictive substances), free sex, abortion, early marriage at risk of exposure HIV / AIDS infection, Sexually Transmitted Infections (STIs) plus Nutrition problems (anemia, chronic energy deficiency (KEK), obesity / overweight). These health problems are not only the responsibility of cross-health programs but also the cooperation of all elements of society and inter-related sectors [5].

Based on the projected population of 2015, the number of adolescents aged 10-24 years in Indonesia reaches more than 66 million or $25 \%$ of the Indonesian Population 255 million (Bapenas, BPS, UNFPA 2013), meaning that one in four Indonesians are Adolescents. The large number is coupled with an increase in the number of teenage births (15-19 years old) and TRIAD KRR (Sexuality, Drugs, HIV / AIDS) [10].

Marriage among teens aged 15-19 pregnant and first childbirth rose from $8 \%$ to 9\% (IDHS 2007 - 2012). Teenage drug users reached 3.6 million people in 2012 and then increased to 3.8 million in $2013^{[11][12]}$.

Profile of Central Kalimantan Provincial Health Office in 2015, data of 2014 number of 18 teenagers aged 15-24 years infected with HIV, seven people suffering from AIDS and two people died from AIDS. Data from 2013 to 2015 in North Barito District, adolescents infected with HIV aged 21-30 years as many as three people by 2013, as many as three 
people in 2014 and as many as 16 people by 2015 [13].

To overcome this problem of teenagers, various prevention and improvement efforts have been done through cross-program and cross-sectoral. BKKBN conducts and responds to adolescent problems through the efforts of population control and family development (Law number 52 the year 2009 article 54), that is through family development policy ${ }^{[2][14]}$. Similarly, the development of the Adolescent Health Program in Indonesia uses the Care of Youth Care (PKPR) approach since 2003[10]. Preliminary study conducted by researchers at Health Service District of North Barito, four Puskesmas have run PKPR service activities [15].

The purpose of this study is to determine the implementation of adolescent reproductive health services special services Health Care Care Youth in four areas Health Centers in Kab. North Barito.

\section{RESEARCH METHOD}

In this study used a qualitative approach, with in-depth interviews with 19 informants consisting of four main informants and 15 informants triangulation. The research design is intended to obtain in-depth information about the implementation of PKPR program based on Input, Process and Output aspects.

First, the researcher conducted in-depth interviews on how the readiness and potential aspects of Input consisting of Human
Resources, Facilities, and Funding. Second, an in-depth interview on what and how resources and services are run. Aspects of the process under study include Information Communication and Education, Clinical Medical, Counseling, Healthy Living Skills Education, Referral and Peer Counselor Training. And thirdly, interviews on the Aspects of Output and Impact Aspects [16] [17].

The research focuses on four PKPR Community Health Centers in North Barito District, Kandui Health Center, Ketapang Public Health Center, Muara Teweh Health Center and Lanjas Community Health Center (Puskesmas Lanjas). In determining the subject of research, sampling technique used is Purposive Sampling. The use of this theory is based on the problems faced by PKPR Puskesmas in North Barito Regency related to several aspects of Input such as untrained PKPR Resources, no PKPR team, less funding and no allocation for PKPR, inadequate infrastructure and not yet maximal implementation of aspects the process of which are six activities of minimum PKPR.

\section{III.RESULTS}

\section{Input:}

\section{Human Resources}

There are three PKPR formed from four Puskesmas. The division of service tasks is not scheduled. Officers have been trained but in 
the implementation of socialization is still integrated with other programs.

\section{Funding}

Existing funding sources come from BOK, APBDes, and BKBPP. Utilization of funds exist but not yet equipped with activity PoA and adolescents are given free according to school card. For the availability of funds and the adequacy of funds not all available because they have to share with other programs.

\section{Infrastructure}

The availability of space and equipment services is limited to only one building that is used in an integrated manner.

Table 1. Availability List of Infrastructure Facilities of PKPR Program Implementation in Four Puskesmas

\begin{tabular}{|c|c|c|c|c|c|}
\hline $\begin{array}{l}\mathrm{N} \\
\mathrm{O}\end{array}$ & $\begin{array}{l}\text { Facilities } \\
\quad \text { available }\end{array}$ & Kandui & $\begin{array}{c}\text { Ketapan } \\
\mathrm{g}\end{array}$ & $\begin{array}{c}\text { Teweh } \\
\text { Tenga } \\
\mathrm{h}\end{array}$ & Lanjas \\
\hline 1 & $\begin{array}{l}\text { Separate service } \\
\text { room }\end{array}$ & $\sqrt{ }$ & $x$ & $x$ & $x$ \\
\hline 2 & $\begin{array}{l}\text { The room is clean } \\
\text { and comfortable }\end{array}$ & $\sqrt{ }$ & $\sqrt{ }$ & $\sqrt{ }$ & $\sqrt{ }$ \\
\hline 3 & $\begin{array}{l}\text { Available trash } \\
\text { cans and hand } \\
\text { wash }\end{array}$ & $\begin{array}{l}\sqrt{ } \\
v\end{array}$ & & v & \\
\hline 4 & $\begin{array}{l}\text { In the room there } \\
\text { are tables and } \\
\text { chairs }\end{array}$ & $\begin{array}{l}\sqrt{ } \\
v\end{array}$ & & v & \\
\hline 5 & $\begin{array}{l}\text { The plot of PKPR } \\
\text { Services is } \\
\text { displayed, which } \\
\text { anyone can see / } \\
\text { read }\end{array}$ & $\sqrt{ }$ & $x$ & $x$ & $x$ \\
\hline 6 & $\begin{array}{l}\text { KIE \& Counseling } \\
\text { Tool (complete) }\end{array}$ & $\sqrt{ }$ & $x$ & $x$ & $x$ \\
\hline
\end{tabular}

\section{Process:}

\section{Communication, Information, Education} (IEC)

IEC activities, coaching, and counseling have been carried out according to the criteria of PKPR at least twice a year in two target schools, a group of religious organizations and three groups of adolescent parents.

\section{Medical Clinical Services}

Teenagers are served according to standardized service procedures. Teenage cases with special problems are kept confidential. But what has not been fulfilled is the availability of Special Medical Records for teenagers, from four Puskesmas only one Puskesmas already available but still inadequate because it has not had its own storage.

\section{Counseling}

Three Puskesmas have been carried out counseling according to the standard procedure but there is no fixed schedule and served in KIA / Nutrition room because not yet have its own space.

\section{Healthy Living Skills Education}

Three Puskesmas have not been implemented this activity has no technical manual and 10 materials of Psychosocial Competence. Peer Counselor Training

Peer Counselor Training is only carried out by one Puskesmas by training 10 junior high school students and 10 high school students from the average of 300 students. Unscheduled activity. Since 2013, it has only been held one time constrained funding as well as the time of the students themselves.

\section{Referral Service}

Four PKPR Puskesmas only established vertical and horizontal Medical Referral Cooperation, no social and legal referrals have been handled in case of an adolescent. 


\section{Output:}

From the results of research on the number of Schools built has been implemented according to PKPR criteria. The frequency of school counseling, there are only two Puskesmas that have been implemented 1-2 times coaching, two other Puskesmas only held every month. For funding has not been optimally utilized and the time provided by the school has not been according to the needs of students.

\section{Impact:}

The result of four Puskesmas, adolescents aged 10-19 years only visited when they were sick and asked for treatment, they have not received the package of PKPR services including promotive, preventive, curative and rehabilitative services which must be given comprehensively in all places of PKPR service. One Puskesmas there is a positive impact of increased knowledge, changes in adolescent behavior and to decrease adolescent health problems. While in three other Puskesmas cannot be seen because the impact of activity has not been active and optimal and recording reporting has not been routinely done. And there is a decrease in school girls' pregnancy cases.

\section{IV.DISCUSSION}

\section{Human Resources}

Based on the results of research on Human Resources aspects, it is found that teenagers have not been served comprehensively through promotive, preventive, curative and rehabilitative efforts in all places of PKPR. Adolescents want privacy, are recognized, respected and involved in planning, implementation, and evaluation of activities [10][17].

This is accompanied by the formation of a team of PKPR accompanied by a Decree of the Head of the Puskesmas including the division of tasks between the Teams such as Drugs on Drugs, Drugs in charge of Doctors, Pharmacists or Nurses, while reproductive health materials are provided by midwives. Two of the three Puskesmas already have a schedule of task distribution between teams. There is already good coordination with the school so that activities can be scheduled on the date arranged by the school. This is in line with Russell P. Harris's research that evidence of good and fair quality must have clear and uninterrupted regulation of primary care and prevention and maintenance services [25].

This research is supported by $\mathrm{Ni}$ Luh Kadek et al. (2013) it is said that the program cannot be completed by the program holder alone, it is necessary to divide the task not only among health workers but also between health workers with school and related sectors [18].

The results of this study in accordance with the National Standard Guidelines PKPR 2014, stated that the health personnel trained PKPR is health workers Puskesmas as members of the team who have received PKPR training conducted by the Provincial 
Health Office or District / City including the related institutions and institutions or orientation to increase insight PKPR with reference to "PKPR Training Manual for Health Workers" conducted internally by Puskesmas. It can be concluded that the improvement of PKPR's insight through PKPR orientation activities can be done internally at the level of Puskesmas with reference to PKPR Training Guidelines.

Furthermore, internal socialization is needed as a form of orientation for all Puskesmas officers by the Head of Puskesmas together with PKPR program managers with the aim to gain common understanding, agreement on the implementation of PKPR and increase the sensitivity of all Puskesmas officers to be able to be friendly teen [17].

External socialization is an effort by Puskesmas to change or influence public policy through various forms of persuasive communication to all stakeholders to gain commitment and support to PKPR program. Stakeholders at the Puskesmas level include Camat, District Health Offices, Schools, Community Leaders, Communities, Private Companies, Youth Concerns NGOs, Parents, Youth Groups, Karang Taruna [17] [18].

\section{Funding}

The results of the study revealed that funding and program limitations were not accompanied by Planning of Action (POA) as well as no special allocation but only extension fees during the health screening to schools. Constraints lie in the lack of advocacy of the program holder, the proposed work plan is not proposed, the lack of internal socialization and the attitude of the Puskesmas tend to ignore the PKPR Program because it is not the Puskesmas Mandatory Program and the number of programs that must be run.

\section{Infrastructure}

Health infrastructure deals with all basic equipment that indirectly supports the implementation of health services such as rooms, buildings and buildings, parking lots and laboratories, tables, chairs, beds, PLN and PDAM installations.

From the research results obtained the availability of special space PKPR is still incorporated with other service program space. This is supported by Permenkes number 75 of 2014 that concerning the Puskesmas space, the number and type of space are determined through the analysis of space needs based on the services held and the availability of resources. Nevertheless requires the management of the space in such a way that in accordance with the concept of PKPR, maintaining privacy, according to the tastes of adolescents and youth-friendly [19].

Related to other supporting facilities such as phantom props, leaflets, flipcharts, game tools, LCD and teenage visit flow owned by Puskesmas are not enough in three Puskemas.

Communication, Information, Education (IEC)

From the results of the research, IEC services have been implemented and at the 
same time, the guidance and discussion of the information and education that is covered include adolescent growth, reproductive health, adolescent nutrition, HIV / AIDS, drug, smoking hazard, and unwanted pregnancy. This is in accordance with the guidelines and standards of Puskesmas criteria are able to carry out the PKPR, among others, is to conduct IEC activities in the target schools at least two times a year [10].

Associated with the competence of officers to adolescents obtained the result that they are satisfied in terms of delivery, mastery of material, appearance and methods of delivering the material. But there are some suggestions for the future that they want a clearer and more concise way of deliberation that is easier to understand, more examples with pictures, multiplied game methods, games, and movie screenings.

\section{Medical Clinical Services}

Based on the results of research, Medical Clinical Services in four Puskesmas obtained by adolescents served according to the standard procedure of handling each disease. Teenage cases with special problems are kept confidential. But what has not been fulfilled is the availability of Medical Records.

PKPR National Standard 2014 mentions that Puskesmas should have a safe (locked) storage area and sufficient for medical records including counseling records so that the right of privacy and confidentiality of adolescent clients is guaranteed. Storage of a separate juvenile counseling file (stored in the PKPR room) and separated from other visiting records at the Polyclinic [24].

\section{Counseling}

Results of three Puskesmas research, Counseling has been implemented but there is no fixed schedule and served in the room KIA or Nutrition because it has no separate space. This is not in accordance with the criteria of PKPR standard, which each activity must also have a Counseling Manual. Adolescent health counseling is counseling given to a teenage client or adolescent group who needs a companion to recognize and solve the problem which in its implementation requires documents or books on which it is based, guidance and guidance) for health workers to carry out the counseling process [10].

\section{Healthy Living Skills Education}

The results of three Puskesmas research have not been done yet because they have no Technical Instruction Book and the subject matter about PKHS.

Related to giving 10 materials Psychosocial Competence in PKHS give impact to adolescent behavior development that is: self-awareness, empathy, decision making, problem-solving, critical thinking, creative thinking, effective communication, interpersonal relationship, emotional control and coping stress [10].

\section{Peer Counselor Training}

From the result of the research, there are three Puskesmas that have not been done Peer Counselor Training. This is due to constrained cost because there are so many other programs 
that must be financed, the constraints of the officers have not been all trained PKPR, but only the orientation is still lacking so that the confusion officers in preparing Peer Counselor Training as well as constraints Puskesmas do not have the Manual on Peer Counseling Training.

\section{Referral Service}

From the results of four Puskesmas research, only medical cooperation is established either vertically (to higher medical services, such as hospitals) and horizontal (from one part in one unit of Puskesmas, for example from PKPR clinic to Dental Polyclinic or STI Clinic). This is not in accordance with the criteria standards of PKPR Guidelines. Although there is no case referral system, a legal and social referral system should be established and prepared with other institutions[20][21]. Referral Service is conducting case referral to higher medical services. Social referrals are also required in the PKPR, for example channeling to work skill institutions for adolescents post-drug abuse[10].

\section{Output}

Output is an element generated from the ongoing process in the system including health services generated by health program units [16].

The outcome is seen from three criteria of Puskesmas capable of implementation of PKPR that has at least 1 school assisted, at least 2 times a year doing coaching / giving KIE to the target schools and train peer counselors as much as $10 \%$ of the total students in the target schools [10].

Furthermore, the frequency of coaching to schools, which must be implemented twice a year, with consideration of the importance of adolescents get a lot of material according to the guidance of the book PKPR and the high health problems of adolescents in the work area.

Low-cost constraints and the time that can be provided by the school for students cause counselor training peer at four health centers PKPR not run as PKPR criteria [16].

\section{Impact}

Impact is the result of the output of the system in the form of the overriding health problems with the consequent increase in the degree of public health [16].

Based on Law Number 23 of 2002 regarding Child Protection, the target of PKPR service users is a group of adolescents aged 10 - 18 years. However, given the age limit of WHO according to WHO is $10-19$ years, hence Ministry of Health set the target of service user of PKPR covers adolescent aged 10 until 19 years, regardless of marital status..

From the results of research in four Puskesmas PKPR stated that positive impacts occur both to increase knowledge, changes in adolescent behavior and to decrease adolescent health problems. As for the negative impact can be seen from the evaluation of activities that have not been active and the maximum and recording reporting has not been routinely done [24]. 
The impact on School Health Program managers states that there is a decrease in pregnancy among schoolgirls. This indicates that there needs to be increased cooperation between the school and health officials related to the reporting system of cases or health problems of adolescents as well as train and enable the function of peer counselors in schools that allow all problems teenagers can be known earlier [24].

Recommendation: Improvement of Adolescent Reproductive Health Services and Adolescent Care Health Services recommended to the District Health Office of North Barito Regency is a) Use of space at the Puskesmas, b) Conduct orientation and training of PKPR for health providers, c) Procurement manual, Peer Counseling Training, socialization and partnership with sector and external stakeholders, and d) Provide information and education to adolescents through social media, banners at school, interactive videos on advertising services on local television. The discussion was also reinforced by the conclusion of Joy Sotolongo, et al, on the services of a teenage reproductive health strategy called Teen Wellness Center (TWC) [22].

And then another strategy model of the Bronx Youth Clinical Model Model in adolescents is also presented by Deborah J. O'Uhuru, 2016 that adolescents are served on quality sexual and reproductive health services [23].

Therefore, the expectations expressed by all informants for PKPR activities must be continuously improved both the quality and the number of Puskesmas PKPR, given the complex health problems of adolescents. It is expected that with the implementation of a consistent, continuous and qualified PKPR program, it can improve the health of youth as the nation's successor.

\section{CONCLUSION}

Overall, the result of this research is concluded that PKPR activities have not run optimally in compliance with the standard of procedure of Guidelines of Implementation and Technical Guidance of PKPR.

Where, Aspect of the Process has not yet been supported by adequate resources both in terms of competence of health workers who have not held adolescent-friendly principles, as well as poor governance and health management systems in terms of monitoring and evaluation and the slowness of follow-up plans. Other issues are also not supported by the commitment of stakeholders at the crossprogram and cross-cutting leadership levels to make breakthroughs and strategies to address adolescent issues by focusing on preventive and promotive efforts.

\section{REFERENCES}

[1]. Profil Kabupaten Barito Utara Tahun 2014. Barito Utara, 2015

[2]. Kementerian Kesehatan RI.. Profil Kesehatan Tahun 2011. Jakarta, 2012.

[3]. Kementerian Kesehatan RI.. Profil Kesehatan Tahun 2012. Jakarta, 2013.

[4]. Izzatun Nurul Rohmah \& Tauran, S.Sos., M.Soc., Sc. Implementation of Youth Care Health Program (PKPR) at Health 
Center Alun Alun District Gresik.

E.Journal. UNESA. Vol 4 No 8 (2016).

Available on:

http://jurnalmahasiswa.unesa.ac.id/index. php/publika/article/view/15963/19954

[5]. Abul Barkhat., PhD., Murtaza Majid, MD. Adolescent and Youth Reproductive Health in Bangladesh: Status, Policies, Program and Issues, Policy Project, Photos selected from M/MC Photoshare at www.jhuccp.org/mmc Photographers (from top): Lauren Goodsmith, Tod Shapera, and Reproductive Health Association of Cambodia, (RHAC), Bangladesh, 2003.

[6]. Michelle J Hindin, Ozge Tuncalp, Caitlin Gerdts, Jessica D. Gipson \& Lale Say, Monitoring adolescent sexual and reproductive health, available at: http://www.who.int/bulletin/volumes94/3/16-170688. Bull World Health Organ 2016; 94:159 doi: http://dx.doi.org/10.2471/BLT.16.170688

[7]. Hilary T. Wolf*, Hayley G. Teich, Bonnie L. Halpern-Felsher, Ramon J. Murphy, Natasha Anandaraja, Jessie Stone et al. The effectiveness of an adolescent reproductive health education intervention in Uganda, Int J Adolesc Med Health 2015, Received April 14, 2015, accepted July 10, 2015.

[8]. Salim E et al. Population Dynamics and Sustainable Development in Indonesia, UNFPA, Indonesia, Jakarta, 2015

[9]. UNPF, BPPN and BPS, Proyeksi Penduduk Indonesia. Population Projection 2010-2035, Jakarta, 2013

[10]. Kementerian Kesehatan RI. Buku Pedoman Pelayanan Kesehatan Peduli Remaja (PKPR). Direktorat Jenderal Bina Gizi dan Kesehatan Ibu dan Anak. Jakarta, 2014.

[11]. BNN Survey Prevalensi Penyalahgunaan Narkoba Pada Kelompok, Pusat Penelitian Data dan Informasi. Jakarta, 2016.

[12]. BNN. Jurnal Data Pencegahan dan Pemberantasan Penyalahgunaan dan Peredaran Gelap Narkoba (P4GN). Jakarta, 2013.
[13]. Profil Kesehatan Kalimantan Tengah Tahun 2014. Dinas Kesehatan Propinsi Kalimantan Tengah, 2015.

[14]. Surya Chandra Surapaty. Sinergi Dukungan Kegiatan dan Anggaran BKKBN dalam Peningkatan Pelayanan KB di Fasilitas Kesehatan, Rakerkesnas, BKKBN, Jakarta, 2017.

[15]. Profil Dinas Kesehatan Kabupaten Barito Utara. Barito Utara, Kalteng, 2015.

[16]. Budioro B. Pengantar Administrasi Kesehatan: Badan Penerbit UNDIP: Semarang, 1997.

[17]. Azwar A. Pengantar Administrasi Kesehatan, Bina Rupa Aksara. Jakarta, 1996.

[18]. Ni Luh Kadek et al. 2013. Peranan Program PKPR (Pelayanan Kesehatan Peduli Remaja) Terhadap Kesehatan Reproduksi Remaja di Kecamatan Buleleng. Jurnal Ilmu Sosial dan Humaniora. Vol. 2, No. 1, April, 2013.

[19]. Kementerian Kesehatan RI. Peraturan Menteri Kesehatan Republik Indonesia Nomor 75 Tentang Pusat Kesehatan Masyarakat. Jakarta, 2014.

[20]. Departemen Kesehatan RI. Pedoman Perencanaan Pembentukan dan Pengembangan Health Center Pelayanan Kesehatan Peduli Remaja di Kabupaten/Kota. Jakarta: 2008.

[21]. Kementerian Kesehatan RI. Modul Pelatihan Pelayanan Kesehatan Peduli Remaja (PKPR) bagi Tenaga Kesehatan. Direktorat Jenderal Bina Gizi dan Kesehatan Ibu dan Anak. Jakarta, 2011.

[22]. Joy Sotolongo, M.S, L.Duane House, Ph.D, Sally Swanson, M.S.PH, M.S.W and Sarah E.H. Davis, M.P.H. Integrated Community Strategies for Linking Youth to Adolescent Reproductive Health Services: A Case Study, 2016, Journal of Adolescent Health, www.jahonline.org, Received March 24, 2016; Accepted November 29, 2016

[23]. Deborah J. O’Uhuru, Vivian Santiago, Ph.D., M.P.H, Lauren E. Murray, M.P.H., M.S., Madeline Travers, M.P.H. and Jane F. Bedell, M.D. Bronx Teens Connection's Clinic Linkage Model: Connecting Youth to Quality Sexual and Reproductive Health Care, New York 
City Department of Health and Mental Hygiene, Bronx District Public Health Office, New York Department of Oral and Maxillofacial Pathology, Radiology and Medicine, New York University College of Dentistry, New York Article history: Received March 24, 2016; Accepted December 17, 2016. https://doi.org/10.1016/j.jadohealth.2016. 12.008

[24]. Lisa M. Romero Dr.P.H. ${ }^{a}$ Oluwatosin Olaiya M.B Ch.B. ${ }^{a}$ Rachel HallumMontes Ph.D. ${ }^{b}$ Balalakshmi Varanasi M.P.H. ${ }^{\mathrm{a}}$ Trisha Mueller M.P.H. ${ }^{\mathrm{a}}$ L.Duane House Ph.D. ${ }^{a}$ et al. Efforts to Increase Implementation of Evidence-Based Clinical Practices to Improve Adolescent-Friendly Reproductive Health Services. Journal of Adolescent Health, Volume 60, Issue 3, Supplement, March 2017, Pages S35S36.
[25]. Russell P. Harris, MD, MPH, Mark Helfand, MD, MS, Steven H. Woolf, MD, MPH, Kathleen N. Lohr, PhD, Cynthia D. Mulrow, MD, MSc, Steven M. Teutsch, MD, MPH et al., Current Methods of the U.S. Preventive Services Task Force (A Review of the Process), American Journal of Preventive Medicine, Volume 20, Am J Prev Med 2001;20(3S) Published by Elsevier Science Inc., 2011. https://doi.org/10.1016/S07493797(01)0 0261-6 